\title{
4 'Get the Prices Right': A Model of Water Prices and Irrigation Efficiency in Maharashtra, India
}

\author{
I. Ray*
}

\begin{abstract}
Much of the world's freshwater is wasted. Governments are shying away from the answer: to price this valuable substance correctly.
\end{abstract}

(The Economist, 23 March 2000)

\section{Introduction}

In the name of food security for the nation and poverty alleviation for the rural population, every developing country provides its farmers with irrigation water at a fraction of its delivery cost (Repetto, 1986). However, growing populations, higher cultivation intensities, increasing urbanization and, of late, environmental concerns, have all combined to put pressure on global water resources. Irrigation is by far the largest consumer of freshwater, and the realization that this water is scarce and getting scarcer has forced a widespread rethinking of the 'cheap water' policy. Elementary economic theory says that farmers who pay next to nothing for water have no incentive to use it efficiently. They could use it to grow waterintensive but perhaps low-value field crops, irrigate carelessly using flood and furrow methods, neglect to maintain their field channels and overwater their standing crops. Water use inefficiency has therefore been cited, in developing and developed countries alike, as an argument for raising the price of irrigation water to reflect its scarcity value.
This policy is now under consideration (and partial implementation) in several countries, from Tunisia to Taiwan and from Botswana to Brazil, including India (Dinar, 2000, Table 1.1). Most country reports on water sector reforms mention - among other things - the need for higher water prices and the removal of flat, per unit-area irrigation charges. In short (irrigation) water is an economic good ${ }^{1}$ and not a birthright, and wasteful water use can best be combated by 'getting the prices right'.

In this chapter, I examine the hypothesis that, in order to induce efficiency at the farm level, irrigation water prices should be raised. In the next section, I set out the rationale for opportunity-cost water pricing, citing modelling and empirical evidence in its

\footnotetext{
*An earlier version of this chapter appeared in ECOnomic and Political Weekly, 13 August 2005. I thank François Molle, Jeremy Berkoff and A. Vaidyanathan for their valuable comments and suggestions on earlier drafts.

${ }^{11}$ Water has an economic value in all its competing uses and should be recognized as an economic good' is one of the four Dublin Principles from 1992 (Solanes and Gonzalez-Villarreal, 1999).
} 
favour. In the third section, I bring out the (often implicit) assumptions under which higher water prices at the farm level can, in fact, increase irrigation efficiency. The fourth section briefly describes the system of canal irrigation in Maharashtra, western India, and introduces the case-study canal. In the fifth section, I show that when these assumptions do not hold water prices have only limited impact on irrigation efficiency. ${ }^{2}$ I illustrate the point with a programming model calibrated to the Mula canal in Maharashtra as a concrete example. ${ }^{3}$ Finally, I analyse a different price policy - specifically, support prices $^{4}$ or procurement prices for particular crops - as an alternative means of conserving water.

Overall, this chapter does not claim that higher irrigation charges cannot induce water conservation, but that they will do so only under several preconditions. If these preconditions are far from ground reality, and I argue that in developing countries they often are, then water prices will not be the best way to save water or to increase its productivity. Transparent and enforced allocation rules may be more feasible, and outputprice policy changes more effective, at least in the near term.

\footnotetext{
${ }^{2}$ The case study in my analysis is not meant to be 'representative' of canal irrigation all over India; rather, it illustrates the role of water prices in a context that shares many features with other canal-irrigated regions.

${ }^{3}$ I focus on canal water prices rather than on groundwater prices for three reasons: first, many analysts believe that canal water is used more inefficiently than groundwater (Dhawan, 1988); second, canal water prices are administratively set and so can be changed through public policy, while most irrigation wells are privately owned; and third, large canal irrigation schemes are the most significant users of freshwater. However, groundwater use in Indian agriculture is growing at a rapid rate.

${ }^{4}$ 'Support prices' are minimum prices that (usually) governments guarantee to farmers. These protect the farmer against low open-market prices. 'Procurement prices', on the other hand, are prices at which a farmer must sell a portion of his crop - usually to the government. These protect not the farmer, but the government and consumers, from potentially high open-market prices.
}

I should note that cost recovery rather than efficient irrigation is another important reason for charging higher water prices. Many developing country governments, India included, are considering higher water prices as a way to recover at least the operating costs of canal systems, and not as a way to reflect the opportunity cost of water. However, the rationale for cost recovery is financial, whereas the rationale for efficient pricing is economic. It is possible to raise water prices to the point where administrative costs are covered, and yet have them lower than the opportunity cost of water. In fact, an adequate per area-irrigated flat fee (that cannot induce efficiency) could cover the capital and operating costs of a canal system. Similarly, efficiency-inducing water prices can coexist with massive subsidies at the system level. The role of water prices for cost recovery purposes is not addressed in this chapter.

\section{Opportunity-cost Pricing: The Evidence}

If water prices rise to reflect its opportunity cost, a profit-maximizing farmer should have any or all of the following four responses (Gardner, 1983). $\mathrm{He}^{5}$ can demand less water and leave some land fallow. He can cultivate all his land but stress the crop a little, thus maximizing his output per unit of water rather than output per unit of land. He can diversify out of thirsty but low water-productivity field and fodder crops into water-efficient crops such as vegetables. And finally, he can invest in efficient irrigation technologies, such as sprinkler and drip systems, which allow a larger fraction of diverted water to be used consumptively by the plant. Even a simple change such as shortening the length of the irrigation furrow could raise field-level irrigation efficiencies by up to $10 \%$. The conclusions of both econometric analyses and

\footnotetext{
${ }^{5}$ am using the term 'he' throughout the paper to refer to individual farmers, because most of the farmers I interviewed for this research were male. There are, of course, both male- and female-headed farm households throughout India.
} 
mathematical programming models imply that farmers could respond to price-induced water scarcity in all these ways. ${ }^{6}$

Much of the literature on water prices is from the agriculturally rich, but water-short, western USA. ${ }^{7}$ Using agronomically derived production functions for cotton, Ayer and Hoyt (1981) show that farmers in Arizona and New Mexico would reduce the water applied over the growing season as its price rises from $\$ 0.5$ to $\$ 5$ per acre-foot. Using Census of Agriculture data for several crops, Ogg and Gollehon (1989) derive downwardsloping, albeit rather price-inelastic, demand functions for irrigation water for the western USA. Caswell and Zilberman (1985), using an econometric analysis of several Californian water districts, find that the probability of adopting drip-irrigation technologies for perennial tree crops increases with increased water prices, among other factors such as land quality and crop type. Kanazawa (1988) asks: what range of price increases will induce conservation? For the Westlands Water District he finds that a three- to fivefold rise would take the price of water to its shadow value and beyond that, farmers would conserve. ${ }^{8}$

It should be noted that in most of these studies on water prices, the response of water use is rather low within observed price

\footnotetext{
${ }^{6}$ There are no controlled experiments in natural settings that have tracked the response of farmers to progressively higher water prices while holding other key variables (more or less) constant. Therefore, the water pricing literature is largely made up of cross-sectional statistical analyses and modelling exercises. However, the latest OECD report on fullcost pricing of irrigation water in Europe questions the accuracy of demand elasticities derived from hypothetical price variations (OECD, 2002).

${ }^{7}$ For reports of European studies, see OECD (2002).

${ }^{8}$ These field studies measured water diverted, not water consumed. Therefore, the production functions used in such research could overstate or understate the yield response to water actually taken up by the crop. Molden (1997) points out that the marginal and average values of water should really be a function of water consumed. This distinction also has implications for how farm-level efficiency and system-level efficiency are measured, as I discuss later in the chapter.
}

ranges. It is only when the price is projected to rise significantly, by a factor of 5 , or sometimes 10, that the water demand is responsive. The consensus from the literature appears to be that the water-demand curve for agriculture is inelastic at low water prices. The elasticity is high when water prices are already high, and when it is cheap and feasible to substitute other inputs, such as labour, for water. For example, Levy (1982), a proponent of regulating water use through the price mechanism, agrees that the price elasticity of water is high when water is readily substitutable and when its share in total production costs is high. I shall revisit these points later in this chapter.

Programming models, which are not restricted to observed price ranges, can yield more elastic water-demand estimates. Many of these confirm the existence of low elasticities at low prices. In a modelling exercise, Weinberg et al. (1993) show that as water prices offered to the farmer rose from 0 to $\$ 50$ an acre-foot, water-intensive crops were no longer optimal, and the amount of irrigation water applied fell. Hooker and Alexander (1998), in a programming model of San Joaquin valley, show that water demand is inelastic over a substantial price range, and steps towards conservation are taken only at certain threshold water prices. However, Howitt et al. (1980) have argued that including a demand function for the crop itself - not just one for water - should generate higher own-price elasticities. ${ }^{9}$

Implementing water trading - as opposed to implementing higher water prices - is another way in which market discipline can be brought to irrigation. Several agricultural regions of Australia are experimenting with intrabasin water trades, such as on the MurrayDarling basin. Spot markets are common in California, and interdistrict water trades, though less frequent than spot trades, do occur (Haddad, 2000; Chong and Sunding, 2006). In the developing country context, informal,

${ }^{9}$ The logic works as follows: higher water prices raise the cost of production which is passed on as higher product prices to the consumer, thus lowering the demand for the product and finally bringing down the derived demand for water. 
intrawatercourse trading exists in Indian and Pakistani canal systems (Bandaragoda, 1998). Short-term sales of groundwater are common although limited in their geographical scope. However, groundwater markets in Gujarat have functioned for many years (Shah, 1993; Dubash, 2002). Tradable water rights refer to longer-term commitments, for an entire growing season or longer. The most celebrated case of such rights comes from Chile, where agrarian reforms and the Water Code of 1981 formalized water rights, and allowed water sales to be separated from sales of land (Bauer, 1997).

In this chapter, I focus on water price policy rather than water trading as a tool for water conservation and irrigation efficiency. I note here, however, that many of the physical and managerial barriers to effective water price reform discussed in this chapter (and elsewhere in this volume) are equally barriers to effective water markets.

\section{What Does It Mean to 'Get the Prices Right'?}

The claim that increasing irrigation water prices is an effective means to irrigation efficiency is much more than a generic statement about downward-sloping demand curves. It contains many assumptions which are not always made explicit and thus need unpacking. These are:

1. Water costs are significant in the overall crop budget, and as a fraction of crop net revenues. (If they are not, the net effect of price increases may be so small that the waterdemand function will barely respond. ${ }^{10}$

2. There is a volumetric link between what a farmer pays and what he receives. (If water is charged by the hectare, as it usually is in developing countries, its marginal cost is zero and higher prices cannot induce efficiency. ${ }^{11}$ 3. Farm-level inefficiencies are significant in relation to overall system inefficiencies.

\footnotetext{
${ }^{10}$ If there are cheap and readily available substitutes for water, this condition need not hold (Levy, 1982).

${ }^{11}$ But they can aid in cost recovery, or cause farmers to withdraw from agriculture altogether.
}

(If this is not the case, the farm may not be the best place to look for water savings.)

4. Farmers irrigate using wasteful methods and/or grow low water-productivity field crops because water is so cheap. (If field crops are grown because local food or fodder markets are thin, or farmers overirrigate because their water deliveries are erratic, water price signals may not have the expected effect.)

5. The changes to the infrastructure that may be necessary to implement volumetric pricing, such as measuring devices, channels for conveyance, managerial and administrative changes, etc., are not prohibitively expensive. (If they are, any gains from more efficient water use will be neutralized by these implementation costs.)

The last item relates to the difficulties of implementing higher water prices on account of institutional or infrastructural barriers. It has borne the brunt of criticisms levelled at water price reform and water markets in the literature to date. Many reservations exist about the inadequate physical infrastructure of canal systems in developing countries, the administrative cost of introducing volumetric pricing (Perry, 1996), the difficulty of measuring water consumed rather than water diverted (Molden, 1997) and the possible third-party effects of water reallocation through pricing or trade (Rosegrant and Binswanger, 1994). The income losses that farmers could face on account of higher prices - especially small and marginal farmers on large canal systems have also been critiqued on grounds of social equity (Chakravorty and Roumasset, 1991). In this chapter, I approach water prices as a means of water saving not from an infrastructural or administrative point of view, but from the point of view of the farmer - the actor who is supposed to do the saving.

I model an Indian canal system - the Mula canal system in Maharashtra - to ask: How effective are higher water prices as a means of curtailing a farmer's water demand, even if transaction and infrastructural costs are assumed not to be constraining? The model is a simplified representation of irrigation in the Mula canal system simplified in order to isolate the effects of water prices on water use and productivity. 
Using a detailed, farming systems model of a median-sized farm, I analyse:

1. Whether higher water charges are the most feasible way to induce farm-level efficiency; 2. Whether farm-level efficiency is indeed as dismal as it is generally thought to be;

3. Whether water prices are the most relevant prices in a farmer's cropping decisions.

The price and input use data for the model, the pattern of water delivery over the agricultural year and the technical coefficients are all from my own 8-month-long fieldwork on the Mula canal system. The net irrigation requirements and the yield responses to water are from studies conducted at the Mahatma Phule Agricultural University at Rahuri, Maharashtra.

\section{Irrigation in Maharashtra and in the Mula Canal System}

The system of irrigation in Maharashtra is demand-based. Before the start of the irrigation season, the farmers who want water submit a demand statement which specifies the land they will irrigate and the crops they will grow. Depending on the water availability that year, the requests are fully or partially granted. The goal of canal systems in India was to ensure a reliable supply of food grains over a large area, even in drought-prone regions, to reduce the risk of famine and the dependence on food imports (Daines, 1985). Accordingly, canal command areas are extensive. ${ }^{12}$ Annual grains and oilseeds are favoured for irrigation, while water-consuming cash crops such as sugarcane need a special 'sanction' (unless they are raised exclusively on groundwater). Dug wells are common in canal-irrigated tracts. Most of the Maharashtra plateau is underlain by basaltic rock; the basaltic layer keeps the water table high

${ }^{12}$ The command area is the area within gravity flow reach of the canal system. The irrigable command area (ICA) is the land that is actually expected to receive water within the command area. On average, major canal systems irrigate half of their official ICA. but the usable volume of groundwater low (Dhawan, 1986).

Canals in Maharashtra are fed by water stored in reservoirs, and are run on an 'on and off' basis (Gandhi, 1981). Only a subset of the watercourses is full of water at any given time. Each watering turn is called a 'rotation'. To compensate for the locational advantage of head-reach farmers, canals are generally (but not consistently) operated from tail to head. When a watercourse has its rotation due, the last field is watered first, and the irrigation turns move up the channel rather than down it. This system is known locally as shejpali. ${ }^{13}$

Traditionally, a farmer could irrigate until his field was 'adequately' wetted. Over time, and especially whenever irrigation demand exceeded the supply, this system came to be seen as too loose. From 1977 onward, the operational rules of major canal systems were gradually modified to a preset number of irrigation hours per hectare of land within each watercourse..$^{14}$ Only the lands and the crops for which the farmer has placed a demand are entitled to water, and this demand could differ from season to season and even from rotation to rotation within a season. The fixed irrigation entitlement, proportional to the area irrigated, is influenced by, but is not identical to, the warabandi system of North Indian canals. ${ }^{15}$ It appears that this modification has introduced greater accountability and predictability in an otherwise overflexible system (Datye and Patil, 1987).

The Mula canal system in western Maharashtra has an irrigable command area of $80,000 \mathrm{ha}^{16}$; the soils are medium-deep

\footnotetext{
${ }^{13}$ The word is derived from shesh (last) and pali (turn).

${ }^{14}$ As a reviewer points out, the more rigid system deprives farmers of the ability to adjust their water use to the actual soil moisture, which can vary by farmer and by season.

${ }^{15}$ The Northern canals are fed by perennial rivers and are run continuously all year. Every hectare in the canal command gets a few hours of water every week, on the same day and at the same time (Gustafson and Reidinger, 1971). This period is his fixed (bundi) turn (wara). Every farmer is entitled to water in every rotation; he need not submit an official 'demand'.

${ }^{16}$ But the area actually irrigated hovers around half that figure.
} 
loams to dark clays; the average annual rainfall in the command is below $600 \mathrm{~mm}$; the median landholding is between 1.6 and $2 \mathrm{ha}$, and even small farms produce crops for the market. The primary crops are sugarcane (a thirsty, lucrative cash crop), wheat and groundnut, followed by sorghum, chickpea and some cotton. Of late, sunflower has grown in popularity. Millet, a coarse grain that was once widely grown and eaten in the region, now occupies less than $10 \%$ of the gross cropped area. The arrival of year-round water has made other crops more profitable.

Water is allocated in the Mula canal system according to the modified fixed-turn system. As described above, it contains elements of Maharashtra's traditional shejpali system, and of the warabandi method of North Indian canals. As under warabandi, canal water is supposed to be delivered to farmers according to a preset rotation schedule - starting about the third week of July (unless it is still raining) and continuing through mid-June of the following year. As with shejpali, it is up to each individual farmer to place, or not to place, a water demand for each rotation of each season. The normal rotation interval - meaning the interval between two successive irrigations for any farm - is 21 days. Between March and June, when midday temperatures peak and the soils have no residual moisture, this interval is shortened to 14 days. ${ }^{17}$ Each hectare is given a fixed duration of irrigation, e.g. $10 \mathrm{~h} /$ ha for a head-end farm and longer if the farm is at the tail end..$^{18}$ In practice, these dura-

\footnotetext{
${ }^{17}$ The 14-day rule applies only to those parts of the canal system that are entitled to summer-season water. In the 1990s, the Right and Left Branch canals were allowed summer water, whereas a third branch, Pathardi, was restricted to an 8-month supply.

${ }^{18}$ The longer per-hour irrigation allowance at the tail end of the canal system is an attempt to compensate for the lower flow rate at the bottom third of long canal systems. The Al/DC ratio, which is the planned area irrigated per day cusec, is lower at the lower reaches and along the distributaries than at the higher reaches and along the main canal. (A day cusec is the volume of water flowing at $28.3 \mathrm{l} / \mathrm{s}$ for $24 \mathrm{~h}$.)
}

tions are 'flexible' (sometimes intentionally and sometimes unintentionally).

The Mula is, in many ways, a typical South Asian canal. The water supply is more generous and more predictable at the head of the system than at the tail; upstream and downstream cropping patterns reflect both the soil variability and the uneven water delivery of the region; often, water does not reach the fields on time; much of the water released into the system is 'lost' in transit, or at least unaccounted for; there is a significant amount of unauthorized irrigation, especially in the upper half of the canal command; and the farmers pay a (small) per-hectare charge for the water they receive. This charge varies by the crop and the season, so there is some attempt, albeit a very loose one, to link water charges and volumes. The command area has several shallow wells, which are largely recharged by canal seepage, and which supplement canal water supplies. The water from these wells is also cheap because electricity for farm use is subsidized. ${ }^{19}$ Irrigation professionals who are familiar with India will recognize many of these features even if they have never been to the Mula canal.

\section{The Farming Systems Model}

In this section, using a mathematical programming model written in GAMS, with numerical parameters calibrated to the upper-middle reaches of the Mula canal, I explore the role of canal water prices on the water use on a hypothetical medium-sized farm. Throughout

\footnotetext{
${ }^{19}$ How to charge for groundwater is an ongoing debate in irrigation policy circles in India. Electricity is cheap and wells are often not metered. The Irrigation Department knows that the wells within a canal command are recharged by canal leakage and it frustrates them that farmers do not pay for groundwater. An obvious option is to raise electricity prices and meter the wells. Even if this were politically simple, which it is not, farmers could counter high electricity prices by switching to diesel-operated pumps. Diesel is subsidized too, but raising diesel prices would affect severa other sectors (tractor power, transportation, residential electricity generation, etc.).
} 
India, Maharashtra included, canal water is charged at a flat per-hectare rate. For modelling purposes, I have assumed that canal water is priced per ha-cm (water depth per hectare, expressed in centimetres) and have converted the relevant per-hectare charges to per ha-cm equivalents. ${ }^{20}$ The 1.6 ha farm in the model is endowed with a male and a female adult, a specified allowance of canal water in each irrigation rotation, and a dug well. The farmer can irrigate from the canal, from the well or from both. ${ }^{21} \mathrm{He}$ is assumed to be profitmaximizing, ${ }^{22}$ so the objective function maximizes the total on-farm profits over the agricultural year, subject to the constraints of land, family labour and the water available from the canal and the well.

The farm is modelled as a linear programme with eight crops (year-long sugarcane; monsoonal sorghum and millet; winter wheat, sorghum and chickpea; and summer season early- and late-sown groundnut) over one agricultural year. With year-round irrigation, the same piece of land can support two, or even three, crops a year. Data on the technical coefficients, output prices, ${ }^{23}$ input prices for hired labour, fertilizers, draft power, etc., and the demand and sup-

${ }^{20}$ Without this volumetric charge assumption, the marginal price of water would be zero, and the model solution would not respond to varying prices. Water prices in the model are lowest for grains and pulses, higher for summer-season crops such as groundnut, and highest for sugarcane - reflecting the official water charges. I have included taxes levied on irrigation water for sugarcane, for education and for the Employment Guarantee Scheme, as part of the 'price' of irrigation water.

${ }^{21}$ In keeping with the geo-hydrological conditions of the Maharashtra plateau, the model well is shallow. The water column varies with the season, and is lowest in summer when crop water needs are at their peak.

${ }^{22} \mathrm{~A}$ profit-maximizing farmer is, by definition, riskneutral. The literature is divided on whether risk neutrality or risk aversion is a more realistic assumption when modelling the small farmer. My fieldwork on the Mula convinced me that risk neutrality was the more appropriate assumption for a median-sized (1.6-2 ha) farmer.

${ }^{23} \mathrm{All}$ prices are quoted in the 1992 value of a rupee: $\$ 1$ = Rs 30, approximately. ply constraints for family labour and water are from field observations and cost-ofcultivation surveys from 67 farm households. The resource constraints for labour and water are separately specified for each 14-21-day period to accommodate the waterdelivery schedule from the canal and the seasonal nature of the agriculture.

As more water is made available per hectare, the yields of most crops increase, but at diminishing rates (Hillel, 1987). To keep the model linear and yet allow the production functions to exhibit diminishing returns, the concave water-response functions are broken up into between four and six linear segments. A crop with a lower water availability than its net irrigation requirement ${ }^{24}$ is treated, in effect, as a separate crop with a lower water requirement, a lower yield and lower labour use. Crops have critical periods when water shortages cause a disproportionate fall in yields, which cannot be reversed by adequate irrigation at other times. For wheat, for example, the most water-sensitive stages are crown root initiation and pre-flowering. To reflect plant physiology as accurately as the data allow, the rotation-wise water requirements take into account any critical growth stage a crop might have. The final model has 36 crops from which the GAMs solver can choose.

The model entitles the farmer to a limited amount of canal water, proportional to his irrigated acreage, at very low crop-specific prices. This approximates the modified rotational water allocation rule in the Mula canal system. The farmer may use all, part

\footnotetext{
${ }^{24}$ The net irrigation requirement (NIR) is the cropspecific and location-specific water required for maximum yields, over and above effective rainfall and stored soil moisture (in a normal year). The seasonal NIRs for the crops are: sugarcane $190 \mathrm{~cm}$, monsoonal millet $25 \mathrm{~cm}$, monsoonal sorghum $30 \mathrm{~cm}$, winter sorghum $38 \mathrm{~cm}$, winter wheat $47 \mathrm{~cm}$, gram $30 \mathrm{~cm}$ and groundnut $70-80 \mathrm{~cm}$. These figures are from the Mahatma Phule Agricultural University and are averages calculated from three separate estimates. The crop-specific water-response functions in the model are derived from IARI (1977) and from unpublished studies at the Water and Land Management Institute, Aurangabad, Maharashtra.
} 
or none of his canal water entitlement in each rotation. The model thus reflects the voluntary demand structure of the shejpali tradition as well as the per-hectare quota of warabandi. In order to analyse the effect of higher canal water prices, three further assumptions have been made. First, in addition to the cheap and limited canal water entitlement, the farmer can buy all the extra canal water he wants at a higher price. In effect, the farmer has access to a cheap baseline block of water and a second, higherpriced tier over and above the baseline entitlement. Second, the farmer can use canal water from either tier to irrigate his sugarcane crop, even if he does not have an official 'sanction' for this crop. ${ }^{25}$ These assumptions are deviations from the actual irrigation rules, but the (hypothetical) effect of water prices on irrigation efficiency cannot be isolated if strict physical quotas and crop-zoning rules are binding constraints on the farmer's decisions. ${ }^{26}$ Third, the model represents an 'average' year, without price and yield fluctuations. This assumption has been added to keep the model tractable as it is already rich in agronomic detail.

\section{Water prices are significant in the overall crop budget}

Canal water prices are heavily subsidized for the farmers on the Mula - so much so that water costs are insignificant in relation to the crops' per-hectare revenues. The surface flow rates in Maharashtra vary by crop so as to reflect (though loosely) the crop's water

\footnotetext{
${ }^{25}$ Another interpretation of this assumption is that there is only very loose enforcement of the cropzoning rules or the sugarcane sanctions. So once the canal water arrives, the farmer can use it as he wants. There is quite a lot of unsanctioned sugarcane in the Mula canal system, and many farmers do, in fact, supplement their well-irrigated sugarcane crops with canal water.

${ }^{26}$ This issue is often blurred in the literature on water prices. If price-based rationing and quantity-based rationing occur together, the physical limit rather than the price could well be the relevant constraint to water use.
}

requirement as well as 'the ability of the crop to bear it' (Pawar, 1985). In 1985, water charges were supposedly fixed at $6 \%$ of the average gross income for food and non-cash crops and at $12 \%$ of the average gross income for cash crops. In practice, they have fallen far short of this goal. For example, water costs for sunflower are $0.77 \%$ of its (average) gross margins ${ }^{27}$ per hectare; for winter wheat this proportion is $0.59 \%$; for summer groundnut $1 \%$; and for sugarcane $1.2 \%$. Sugarcane, the most water-intensive of these crops, and the one to which critics of low water prices regularly refer, is in fact the least subsidized in terms of its relative water costs.

All the (previously cited) evidence on own-price elasticities suggests that water demand will not respond to price increases when the base price of water is so low. In addition, the existing system of per-hectare water prices means that the marginal cost of water is zero for each crop. It is true that higher water fees for water-consuming crops might induce a farmer to switch over to less water-intensive crops, or even to withdraw from farming altogether. However, prices would have to be raised by several hundred percent before water costs reach even $5 \%$ of a crop's gross margins.

An alternative proposal would be to physically ration the water given to agriculture, and to each irrigated hectare. ${ }^{28}$ That is, no second tier of canal water could be bought. Recall that all the ways in which a farmer could respond to higher water prices fallowing land, switching crops, etc. - require him to lower his total or his per-hectare water use. Rationing would directly force him into a lower, and potentially more efficient, water use pattern. By comparing the farmer's crop choices under low prices with rationing, and under successively higher water prices without rationing, we can ask:

1. At what price are the farm-level irrigation demands comparable with and without water rationing?

\footnotetext{
${ }^{27}$ Gross margin means revenues minus variable costs, on a per-hectare basis.

${ }^{28}$ The difference between this proposal and current water-allocation laws is that current law calls for croppattern restrictions in addition to a water quota.
} 


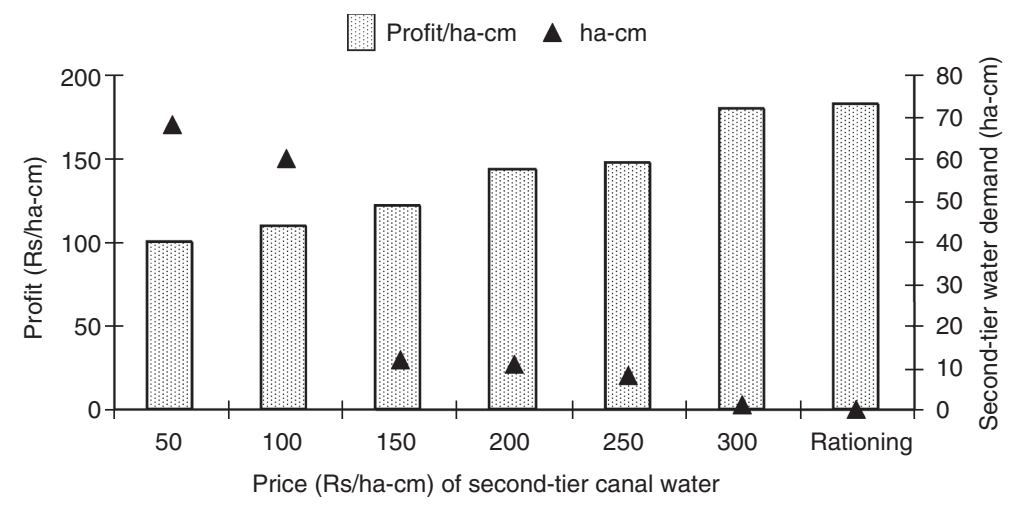

Fig. 4.1. Canal water prices and net revenues per unit of water.

2. Can we estimate the net revenues per unit of water applied ${ }^{29}$ under various water price and crop choice scenarios?

Figure 4.1 plots the net revenues per unit of water, the price of canal water and the onfarm water demand from running the model at successively higher water prices. The $x$-axis shows the price per unit of canal water over and above the farmer's baseline entitlement. The secondary $y$-axis shows the model solution for the farmer's additional water use at the relevant price. ${ }^{30}$ The primary $y$-axis plots the net revenues per unit of water applied, from the

${ }^{29}$ Net revenues per unit of water' means the annual total on-farm profits divided by the annual total quantity of irrigation water used.

${ }^{30}$ To explain in more detail, the $x$-axis shows the additional price of canal water for quantities above the baseline ration - i.e. it is the price of second-tier canal water. The average price of water actually paid by the farmer depends on the precise mix of baseline canal water, second-tier canal water and well water he uses. This average price will always be lower than the price of the above-the-baseline canal water shown on the $x$-axis. The primary $y$-axis shows the average value of water used on the farm - computed annually over all crops and using all three water sources. Ideally, we would like to compare the marginal price of water to its marginal value, but this rises and falls each month for each crop and could not be shown on a graph. We could also run this model for a farmer without a well, so that canal water prices would affect only canal water demand. But since most median-sized farmers of this region do have wells, and the use of well water is affected by availability of canal water, such a model would not have yielded a realistic cropping pattern. canal and the well, on the farm. ${ }^{31}$ Sugarcane is the crop with the highest annual water requirement, and agronomic experiments show that sugarcane has low returns per unit of water used, but high returns per unit of land (Rath and Mitra, 1989). Hybrid grain varieties and oilseeds generally yield higher revenues per unit of water applied. Therefore, a cropping pattern that is water use-efficient should have less sugarcane and more seasonal crops such as wheat.

In each price scenario in Fig. 4.1, the farmer is allowed a cheap but limited volume of canal water (the first tier) which he can apply to any crop. In the rationing scenario, this is all he is allowed. The model solution shows that, when a farmer's water is rationed according to proportional allocation rules, a 1.6 ha plot would have 0.56 ha of sugarcane (which has a growing season of 12 to 14 months), and a winter-summer cycle of wheat followed by groundnuts on his remaining land. (This wheat-groundnut cycle is indeed common in the upper-middle reaches of the Mula.) If he can buy all the extra water he wants beyond the minimum entitlement, he grows 1.6 ha of sugarcane at a 'second tier' price of Rs 50/ha-cm and less

\footnotetext{
${ }^{31} \mathrm{My}$ assumption in the model is that the farmer's objective function is to maximize his total farm profits, not the output or economic returns per unit of water used. However, 'more crop per drop' or 'more value per drop' are the goals of water efficiency in agriculture, which is what we want to measure here.
} 
and less sugarcane as water prices rise, and finally replicates the rationing crop pattern at a price of Rs 300/ha-cm. At Rs 150/ha-cm the water demand has dropped sharply, and at Rs 300/ha-cm the net returns to water are comparable to those under rationing. A rate of Rs 150/ha-cm represents a more than tenfold increase over the average price of the baseline water block.

For the near future, such severe waterprice hikes are unlikely to be suggested, let alone implemented. Farmers are numerous, and they vote. They object vociferously to price increases in water or electricity (The Economist, 1997), especially since such price hikes are usually unaccompanied by better or more reliable services. Price increases of this magnitude would have to be introduced in stages, and over time, at least in democratic regimes which are less able to implement swift policy changes (Dinar, 2000)..$^{32}$ Nor would the urban population support rapid price increases, out of fear that their food costs would rise, or that national food security would be compromised. As Sampath (1992) points out, urban consumers of cheap food benefit at least as much from subsidized irrigation water as do the farmers. In short, in this region, significant price increases seem to be politically infeasible, and feasible price increases are economically insignificant. ${ }^{33}$

Finally, water fee collections on the Mula, as on most other Indian canals, are poor. Pawar (1985) estimates that major irrigation systems recover about $67 \%$ of their expected annual fees and minor systems recover just over $50 \%$. The Irrigation Department's own (unpublished) records show that, from 1977 to 1990, collections on the Mula ranged from a low of $15 \%$ of the expected annual total to a high of $64 \%$. Had the uncollected balances been rolled over from year to year in the accounts, these

\footnotetext{
${ }^{32}$ raised the issue of raising irrigation water prices (just enough to cover the annual operation and maintenance costs) at the Command Area Development Authority for the Mula canal. The response of the Chief Engineer was brief: 'You must be mad.'

${ }^{33}$ This situation is not unique to India. Empirical work on the Zayandeh Rud basin in Iran (Perry, 2001), for instance, had similar implications.
}

percentages would have been even smaller. If canals in India have been unable to recover their annual operation and maintenance costs, the state's inability to collect water fees is at least as much to blame as the low water charges themselves. ${ }^{34}$

\section{Farm-level inefficiencies are a significant part of overall inefficiencies}

If higher water prices are expected to improve irrigation efficiencies, it seems reasonable to ask how inefficient water use at the farm level really is, and what the relationship is between water prices, main system management and farm-level inefficiencies.

Farmers on the Mula canal - and in much of southern India - do flood-irrigate their sugarcane and grain crops, and they do allow water to spill beyond the borders of their fields. Rarely do they channel their water carefully through their furrows, or put a lot of labour into land preparation and levelling, as farmers trying to conserve water would do. The field channels are usually poorly maintained, allowing seepage and runoff losses, as even casual observation would reveal. These losses increase non-linearly down the system; seepage and evaporation reduce the flow rates to the tail end, and the slower flowing water then seeps out at an even higher rate.

It is now well understood that these local seepage and runoff losses are not necessarily lost to the basin. In a pioneering paper, Frederiksen (1992) distinguished farm- and project-level efficiency from system-level efficiency and argued that it was worth investing in irrigation efficiency in the lower reaches of a basin but not necessarily upstream. This is because seeped water re-enters the system as return flow

\footnotetext{
${ }^{34}$ During my fieldwork, new canal water rates were proposed for the state of Maharashtra. They were modestly higher than the existing rates, but some farmers in the Mula canal system were unhappy with the proposal. When I mentioned this to the Sub-Divisional Officer with whom I worked, he seemed genuinely surprised. 'Why are they angry? They don't pay us anyway.'
} 
where it has instream uses or recharges the water table or can be diverted again. Thus, the water 'saved' in one part of the system, through price incentives or other means, may not be a net saving at all (Seckler, 1996). Bromley (2000) critiques the notion that irrigation water should be optimally used on the individual farm, and recommends that canal water be priced recognizing that it is a common property resource and that optimality is a system-wide concept.

Of course, some return flows become saline and unusable. On the other hand, water which recharges a well over which the farmer has complete control, and which can be used in the dry intervals between canal deliveries, has a very high marginal value. ${ }^{35}$ The farming systems model shows that, in the parched month of May, one additional inch $(2.5 \mathrm{~cm})$ of well water had a marginal value equal to $1 / 12$ of the profits from a hectare of groundnut.

But let us assume, for the sake of argument, that most of the seepage and runoff is irretrievably lost. What fraction of these losses occurs at the field level? Large canal systems in India consist of one or two main or major branches, then several distributaries that further divide up into minor branches, and finally a network of watercourses and field channels. Irrigation takes place at the level of the watercourses and field channels. Actual transmission losses are not measured (or at least, are not published) regularly in India, especially downstream of the distributary outlets. However, transmission losses in four canal systems of Maharashtra just from the main canals to the distributary heads - have been estimated at between $10 \%$ and 59\% (Rath and Mitra, 1989).

The Irrigation Department of Maharashtra measured the rates of flow down the length of the Mula canal to estimate its transmission losses - without taking into account any return flows - in the mid-1980s. ${ }^{36}$ The cumulative measurements of conveyance, evaporation

\footnotetext{
${ }^{35}$ The number of wells in the 360 ha study area increased from 22 to 183 within 15 years of the canal being extended to the region.

${ }^{36}$ The exact date is unclear. I obtained these data from unpublished reports at the offices of the Irrigation Department, Government of Maharashtra, in Ahmednagar.
}

and other losses ${ }^{37}$ along the canal were as follows: from the reservoir to the distributaries the flow had dropped by $35 \%$; from these to the minor heads by $42 \%$; and from the minors to the farms themselves by $65-70 \%$. The farmer can be given price 'incentives' to be efficient with at most $30-35 \%$ of the irrigation water diverted from the reservoir. This is all the water that he has control over.

\section{Farmers are inefficient in their water use because water is cheap}

Locational asymmetry is a well-known phenomenon along major gravity-flow systems such as the Mula. Downstream farmers get less water than their upstream neighbours, and to make matters worse, their water deliveries are often delayed. For example, water from the Mula canal is supposed to arrive at 21-day intervals for the winter crop season, and 14 days apart in summer. In spite of the more frequent water supply in the hot season, this is a period of great stress. The clayey soils of the Maharashtra plateau are normally water-retentive but by April they are dry and cracking, and pan-evaporation rates can be as high as $15 \mathrm{~mm} /$ day (Lele and Patil, 1991). Despite these conditions, planned and actual water deliveries move further and further apart as they proceed down the canal. Table 4.1 shows the actual delivery intervals for one particular watercourse in 1991, which was not even a tailend watercourse.

Many farmers openly admit that they take extra water and flood their fields generously when the water finally arrives. 'I just grab as much water as I can,' said a sugarcane farmer. 'The government says that's wasteful, that other people need water too. But what else can I do?' And in the words of a smaller farmer, lower in the system: 'The canal water

\footnotetext{
${ }^{37}$ 'Other' upstream losses include illegal water diversions, mostly for unauthorized sugarcane or for irrigation outside the official command area. Illegal irrigation is often not efficient, but, if it goes unchecked, it can hardly be made efficient through higher water prices (Ray and Williams, 2002).
} 
Table 4.1. Example of irrigation delivery intervals on the Mula canal.

\begin{tabular}{llcl}
\hline $\begin{array}{l}\text { Winter } \\
\text { irrigation No. }\end{array}$ & $\begin{array}{l}\text { Interval (days) } \\
\text { (planned = 21) }\end{array}$ & Summer irrigation No. & $\begin{array}{l}\text { Interval (days) } \\
\text { (planned = 14) }\end{array}$ \\
\hline 1 & Inapplicable & 1 & Inapplicable \\
2 & 18 & 2 & 20 \\
3 & 26 & 3 & 18 \\
4 & 31 & 4 & 24 \\
5 & 27 & 5 & 34 \\
6 & 24 & - & - \\
\hline
\end{tabular}

is like the rain. It may come, it may not come, it may come late. If it comes, we are happy. But my brothers and I, we can't rely on it.'

Farmers who do not know when to expect water, or have to plan for long dry intervals between irrigations, can be forced into stress-tolerant, possibly low-valued field crops. This is especially true of downstream farmers who typically have fewer opportunities for unauthorized irrigation, and of farmers without access to supplementary groundwater. The irrigation literature frequently implies that low water prices cause farmers to grow low-productivity crops such as lucerne and coarse grains, and that higher water prices would make them switch to, for example, vegetables and finer cereals. Water is cheap, and crops with low returns to water are grown, but such observations do not establish causation. An equally plausible hypothesis is that higher-productivity crops (such as groundnut or sunflower) need a steady supply of water at regular intervals, whereas crops such as millet or sorghum can make do with less water, less precisely timed. ${ }^{38}$ To isolate the effect of delays in the

\footnotetext{
${ }^{38}$ Other plausible hypotheses exist: field crops or coarse cereals are grown because of labour constraints, or a shortage of cash or credit to buy inputs for the more profitable crops, or are needed for home consumption if the local grain markets are thin. In this section, I analyse only the effect of irrigation delays. It can also be argued that poor farmers are risk-averse, that they choose crops with low returns to water and/or land rather than higherproductivity crops whose yields may fluctuate. The model solution shows that even risk-neutral farmers could choose to grow crops with low returns to water and/or land with untimely water supplies.
}

water-delivery schedule, the original farming systems model was modified as follows:

1. The wells were taken out, so that the impact of canal water deliveries could be evaluated from the perspective of the most vulnerable farmers - those without supplementary groundwater. These farmers are entirely dependent on the canal, either because they are too poor to have a well or because the local hydrological conditions cannot support a well with reliable yields.

2. The arrival of water in a specific rotation was delayed, but compensated for in the next rotation. Therefore, the annual volumes of water delivered are unchanged from the original model.

3. Quantity restrictions were put in place; the farmers were not entitled to water over and above their first-tier allocations.

4. Water prices were kept low.

Three versions of the model were run, with delivery delays in March, April and May, respectively. ${ }^{39}$ In each case only one rotation is delayed and the model treats the delay as anticipated. In reality, delays can be approximately known in advance (from past experience), or genuinely unexpected. In the second case, the effect on yields and revenues can range from a significant drop in yields to total crop failure. In the first case, which is modelled here, the farmer

\footnotetext{
${ }^{39}$ I focus on these months because they are hot, and so the crops are most sensitive to delayed water deliveries. Delayed kharif season deliveries, by contrast, would usually be less damaging; and Irrigation Department records show that in the upper-middle reaches in the Mula canal system the irrigation demand for kharif season crops is, in any case, low.
} 


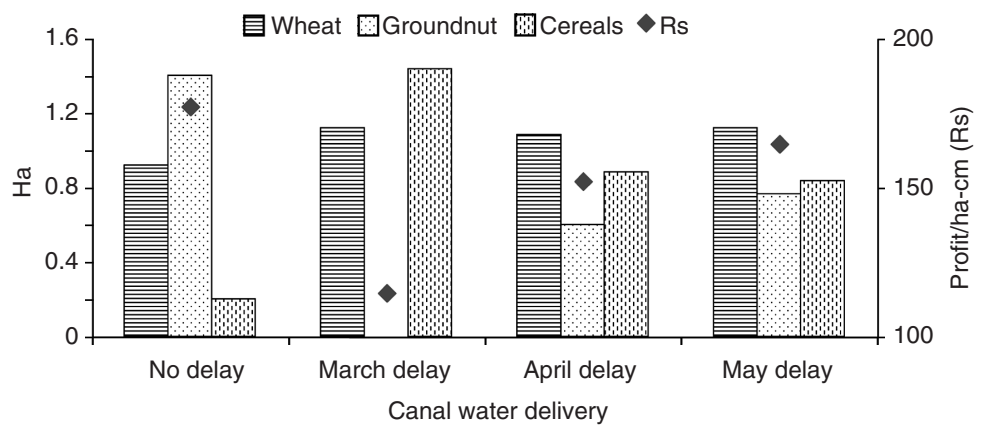

Fig. 4.2. Water-delivery regimes, crop patterns and profits.

can adjust his crop choices at the start of the season. The model solutions therefore represent the best-case delay scenarios. The solutions are explained in some detail to illuminate the connections between water deliveries and crop choices.

Figure 4.2 compares the cropping patterns and the net revenues per unit of water on a 1.6 ha farm under the planned waterdelivery schedule, with those under late water arrivals in March, April and May. The water-delivery regime is shown on the $x$ axis. The optimal cropped areas under wheat, groundnut and coarse cereals (meaning, millet and sorghum) under each regime are plotted on the primary $y$-axis. These areas add to over 1.6 ha because of multiple cropping over three seasons. The returns per ha-cm of water are shown on the secondary $y$-axis. There is no sugarcane in these model solutions, not because of risk aversion or a desire for food security, but because of the high and year-round water needs of sugarcane. Sugarcane remained in the model as a crop choice, but with strict canal water rationing in place, it appears not to be a viable option without a well or a 'sanction'.

During informal conversations in the field, farmers without wells in the Mula command overwhelmingly preferred a wintersummer rotation of wheat (average gross margin Rs 7500 at 1992 prices ${ }^{40}$ and groundnut (average gross margin Rs 10,000). The coarser cereals (gross margins between Rs

${ }^{40}$ The numbers themselves are location-specific, of course.
2000 and Rs 4500) were mostly grown on rain-fed land or if the water supply was inadequate for a larger groundnut crop. ${ }^{41}$ The model solution with no water delays reflects this ground reality, with its wheat- and groundnut-dominated cropping pattern. If the farmer expects a long dry spell in April or May, he opts for a smaller groundnut crop and a larger cereal crop - as well as a drop in his water productivity. But a delay in March is the most damaging of all. March is not a particularly water-demanding month, but that is when groundnut is planted, and when a presowing wetting is really critical. Figure 4.2 shows that an irrigation delay in March cannot be made up by extra water in April, and that the farmer is forced into a monsoonwinter rotation of coarse staples followed by wheat - a low-value combination. Land records confirm that this monsoon-winter food grain pattern was common in the region before the arrival of canal irrigation.

If farmers overirrigate as a hedge against future shortfalls, or accept low returns to land or water because their canal water deliveries are untimely, they are not going

\footnotetext{
${ }^{41}$ Groundnuts are summer crops and coarse cereals are monsoonal crops. Nevertheless, they often compete for the same piece of land. If groundnuts are sown early, the land can be cleared in time for the monsoonal or kharif grain crop. If they are sown late, there is too short an interval between harvesting the summer crop and sowing winter (rabi) wheat to support a kharif crop. The model solutions accurately reflect the Mula farmers' preference for the wheat plus late-sown groundnut crop cycle.
} 
to become efficient as a result of higher water prices. To what extent farm-level inefficiencies - which certainly exist - are significant in relation to, or are themselves a response to, main system inefficiencies is a very important question. Irrigation water prices can affect only that water over which the farmers have some control, and only those inefficiencies which are caused by low water prices. ${ }^{42}$ In the current situation, higher water prices - if collected - are likely to lower farmers' net revenues, but have only a marginal impact on overall water-use efficiency.

\section{Water Prices versus Crop Support Prices}

Finally, if we must look to the price mechanism as a way to induce water efficiency, we should ask if water prices are the most relevant prices. In the Mula canal system, sugarcane is the cash crop of choice for both large and small landholders. The sugarcanecrushing mills, which are given a subsidy per tonne of sugarcane processed, guarantee a high support price to sugarcane producers. There is thus relatively little price risk with sugarcane compared to other cash crops such as sunflower or groundnut. In 1992, the average farm-gate price reported from this area was Rs 35/quintal. ${ }^{43}$ The support price guaranteed by the state of Maharashtra was Rs 29/quintal. The average producer's cost, calculated from my own cost-of-cultivation surveys, was just above Rs 21.

\footnotetext{
${ }^{42}$ The 1992 Planning Commission Report on irrigation pricing, chaired by Professor A. Vaidyanathan, in fact, concluded that irrigation charges should be raised, but that improving the physical condition of the main system, the timeliness of water deliveries and a higher rate of fee collection are preconditions for higher prices to be effective (Gol, 1992).

${ }^{43} \mathrm{~A}$ quintal is equal to $100 \mathrm{~kg}$. At the time, this price represented an effective nominal protection coefficient (NPC) for raw sugarcane of almost 1.5. The NPC was computed through the procedure followed by the World Bank to estimate the unsupported price of sugarcane as a fraction of the international price for raw sugar.
}

Sugarcane is popular for its high and certain returns to land (the sugarcane-crushing factories pay farmers more than the government support price), for its resistance to pests, and for its low labour requirements compared to water-efficient crops such as vegetables, oilseeds or spices. The programming model of the representative farm was run again, this time keeping canal water prices at their low 'first tier' values, allowing the farmer to buy as much water as he desired at those low prices, letting him choose to irrigate from the canal, from his well or from both, and parametrically varying the price of sugarcane. The difference between this model and the version that varied canal water prices is that, in this version, first- and second-tier canal water has the same price. This model specification allows us to analyse the role of sugarcane prices in the absence of high water prices or water-quantity constraints.

The model solution shows that had the government not supported the price of sugarcane, or subsidized the sugarcane-crushing facilities, it would have been unprofitable for the farmers to grow sugarcane (Fig. 4.3). When sugarcane prices (shown on the $X^{-}$ axis) fall, the area under sugarcane (plotted on the primary $y$-axis) and the water used on the farm (on the secondary $y$-axis) both drop sharply. A $14 \%$ drop in the price of sugarcane triggers a $28 \%$ drop in the water demand $^{44}$ and the equivalent response would have required a nearly fourfold rise in the price of canal water charged at sugarcane rates. At sugarcane prices of Rs 25, even at low water prices, farmers would switch completely to a cycle of winter wheat followed by summer groundnut. That repre-

\footnotetext{
${ }^{44} \mathrm{Although}$ this hypothetical farm is endowed with a well, the model solution shows that the $28 \%$ drop in water demand is entirely from the canal. Well water is cheaper than canal water used for sugarcane, so the profit-maximizing farmer uses up his well water before buying canal water. Similarly, canal water is the first source of water he cuts if he reduces his overall demand. As the farmer opts out of sugarcane altogether, canal water for seasonal crops and well water can be used interchangeably since they cost about the same.
} 


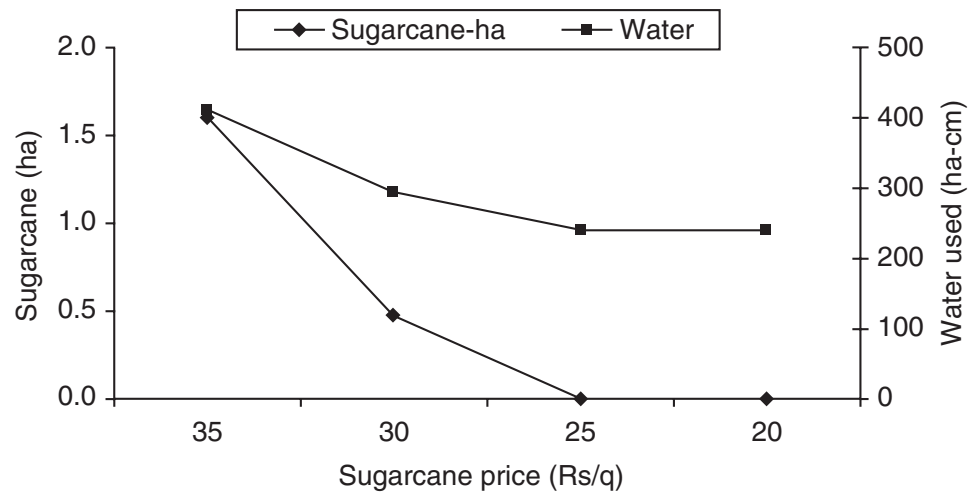

Fig. 4.3. Optimal sugarcane area and annual water use on a 1.6 ha farm; varying cane prices and low water prices.

sents a water-conserving choice not induced by higher water prices.

Maharashtra produces about $14 \%$ of India's sugarcane (by cane weight) and has approximately $12 \%$ of India's cropped area under sugarcane (Pant, 1999). If the government did attempt to remove the support price, it would find a powerful, wellorganized and hostile opponent in the sugarcane-processing lobby (Attwood, 1985). Sugarcane-growing farmers, too, would be up in arms as the removal of price supports for raw sugarcane causes farmers' net incomes to fall. As I have earlier argued, drastic rises in water prices may not be feasible either - at least not over a short time period. A discussion on the comparative politics of higher water prices versus lower sugarcane prices is beyond the scope of this chapter. But the analysis presented here indicates that if we want to use price policy to reduce the demand for irrigation, or to induce efficient crop diversification, output rather than water prices may be an equally effective and a more direct route.

\section{Conclusion}

Economists are right when they point out that irrigation water prices are absurdly low compared with its scarcity value, and that at such low prices there is no incentive to conserve. However, it does not follow that rais- ing water prices is the natural next step for developing countries such as India. From the perspective of the farmer who is supposed to save the water, I have suggested that there are two broad reasons for this conclusion. First, in the short to medium term, canal water prices cannot be raised to the point where they can significantly affect water demand. The negative impact on farm revenues would be too drastic and the policy would not find broad support. Second, low water prices are often not the main reason behind water-inefficient crop choices. Moreover, farm-level inefficiencies appear not to be the most significant inefficiencies on existing canals; nor are water prices the most significant prices driving irrigation demand.

A better first step would be to enforce simple allocation rules, such as a per-hectare ration that would make the scarcity value of water immediately obvious. This step, while hardly simple, could be more politically feasible than raising prices sharply, because quantity restrictions are already the basis of water allocation in most Indian canals. The rules are rather loosely followed at present (Wade, 1982; Ray and Williams, 2002), but a concerted attempt to implement them better would be perceived as fair, and would have the support of many middle- and tail-end farmers. There is also considerable field evidence that water users' associations (WUAs) could be helpful in implementing water allocation rules (Wade, 1988; Ostrom et al., 
1994), though WUAs are no guarantee against inefficiency (Vermillion, 1997). Physically rationed water shares that are transparent and enforced can also free up water to be transferred to urban areas, or to increase the number of farmers with access to canal water, or to meet environmental needs.

Proponents of water pricing certainly recognize that the price mechanism has to be embedded in a carefully designed institutional framework (GoI, 1992; Sampath, 1992; Saleth, 1997). From most of these analyses, however, it remains difficult to isolate the (efficiency) impacts of water prices from those of all the other recommended physical and institutional reforms. More research is also needed on whether enforcing simple allocation rules would be more, or less, costly to administer than a completely new tariff structure; it could be that the cost of restructuring water charges, under a range of conditions, is higher than the expected efficiency gains (Tsur and Dinar, 1997). Yet, over the last two decades, and especially since the Dublin Principles declared water to be an economic good, the mainstream literature on water sector reform has been significantly focused on the need for higher water prices and more water trades. In this chapter, I have argued that water may be cheap, and that water use in agriculture may be inefficient, and that these are indeed problems. But the case study of Maharashtra shows that low water prices are often not the most immediate causes for irrigation inefficiency, and so we cannot conclude that 'getting the prices right' is the most appropriate solution.

\section{References}

Attwood, D.W. (1985) Peasants versus capitalists in the Indian sugar industry: The impact of the irrigation frontier. Journal of Asian Studies 45, 59-80.

Ayer, H. and Hoyt, P.G. (1981) Crop-Water Production Functions: Economic Implications for Arizona. Technical Bulletin No. 242. University of Arizona, Tucson, Arizona.

Bandaragoda, D.J. (1998) Design and Practice of Water Allocation Rules: Lessons from Warabandi in Pakistan's Punjab. Research Report No.17. International Water Management Institute, Colombo.

Bauer, C.J. (1997) Bringing water markets down to earth: The political economy of water rights in Chile, 1976-1995. World Development 25, 639-656.

Bromley, D. (2000) Property regimes and pricing regimes in water resource management, Chapter 2. In Dinar, A. (ed.) The Political Economy of Water Pricing Reforms. Oxford University Press, New York.

Caswell, M. and Zilberman, D. (1985) The choice of irrigation technologies in California. American Journal of Agricultural Economics 67, 224-234.

Chakravorty, U. and Roumasset, J. (1991) Efficient spatial allocation of irrigation water. American Journal of Agricultural Economics 73, 165-173.

Chong, H. and Sunding, D. (2006) Water markets and trading. Annual Review of Environment and Resources 31, 239-264.

Daines, S.R. (1985) Irrigation Policy in India: Historical Trends and Public Policy Issues. Irrigation Sector Strategy Review, Water Management Synthesis Report No.35. Utah State University, Logan, Utah.

Datye, K.R. and Patil, R.K. (1987) Farmer Managed Irrigation Systems - Indian Experiences. Centre for Applied Systems Analysis in Development, Pune, India.

Dhawan, B.D. (1986) Economics of Groundwater Irrigation in Hard-Rock Regions. Agricole Publishing Company, New Delhi.

Dhawan, B.D. (1988) Irrigation in India's Agricultural Development: Productivity, Stability, and Equity. Sage Publications, New Delhi.

Dinar, A. (2000) Political economy of water pricing reforms, Chapter 1. In: Dinar, A. (ed.) The Political Economy of Water Pricing Reforms. Oxford University Press, New York.

Dubash, N. (2002) Tubewell Capitalism. Oxford University Press, New York and New Delhi.

Frederiksen, H. (1992) Drought Planning and Water Efficiency. World Bank Technical Paper No.185. World Bank, Washington, DC.

Gandhi, P.R. (1981) History and Practice of Management of Irrigation Waters in Maharashtra. Water and Land Management Institute, Aurangabad, India. 
Gardner, B.D. (1983) Water pricing and rent-seeking in California agriculture. In: Anderson, T.L. (ed.) Water Rights, Scarce Resource Allocation, Bureaucracy and the Environment. Ballinger Publishing Company, Cambridge, Massachusetts, pp. 83-113.

Gol (Government of India) (1992) Report of the Committee on Pricing of Irrigation Water, Planning Commission. Government of India, New Delhi.

Gustafson, W.E. and Reidinger, R.B. (1971) Delivery of canal water in North India and West Pakistan. Economic and Political Weekly 6, A157-A162.

Haddad, B. (2000) Rivers of Gold: Designing Markets to Allocate Water in California. Island Press, Washington, DC.

Hillel, D. (1987) The Efficient Use of Water in Irrigation. Technical Paper No. 64. The World Bank, Washington, DC.

Hooker, M.A. and Alexander, W. (1998) Estimating the demand for irrigation water in the Central Valley of California. Journal of the American Water Resources Association 34, 497-505.

Howitt, R.E., Watson, W.D. and Adams, R.M. (1980) A re-evaluation of price elasticities for irrigation water. Water Resources Research 16, 623-628.

IARI (Indian Agricultural Research Institute) (1977) Water Requirements and Irrigation Management of Crops in India. New Delhi.

Kanazawa, M. (1988) The economic efficiency of irrigation water supply by agricultural water districts: An econometric analysis. University of California at Berkeley, California. Draft.

Lele, S.N. and Patil, R.K. (1991) Working for Farmer Participation in Irrigation Management in Major Irrigation Projects. Centre for Applied Systems Analysis in Development, Pune, India.

Levy, Y. (1982) Pricing federal irrigation water: A California case study. In: Energy: The Next Twenty Years. (Report sponsored by the Ford Foundation, chaired by H.H. Landsberg.) Ballinger Publishing Company, Cambridge, Massachusetts.

Molden, D. (1997) Accounting for Water Use and Productivity. SWIM Paper 1. IIMInstitute, Colombo.

OECD (Organization for Economic Cooperation and Development) (2002) Transition to full-cost pricing of irrigation water for agriculture in OECD countries. Available at: COM/ENV/EPOC/AGR/CA(2001)62/ FINAL. Downloaded 03/2006 from http://www.olis.oecd.org/olis/2001doc.nsf/

Ogg, C.W. and Gollehon, N.R. (1989) Western irrigation response to pumping costs: A water demand analysis using climatic regions. Water Resources Research 25, 767-773.

Ostrom, E., Gardner, R. and Walker, J. (1994) Rules, Games and Common Pool Resources. University of Michigan Press, Ann Arbor, Michigan.

Pant, N. (1999) Impact of irrigation management transfer in Maharashtra. Economic and Political Weekly, Review of Agriculture, 27 March-2 April.

Pawar, J.R. (1985) Recurrent cost study of operation and maintenance of irrigation systems in Maharashtra. In: Daines, S.R. and Pawar, J.R. (eds) Irrigation Sector Strategy Review, Water Management Synthesis Report, Appendices Volume II. Utah State University, Logan, Utah.

Perry, C.J. (1996) Alternative Approaches to Cost Sharing for Water Service to Agriculture in Egypt. Research Report No. 2. International Irrigation Management Institute, Colombo.

Perry, C.J. (2001) Charging for Irrigation Water - the Issues and Options in Iran. Research Report No. 52. International Water Management Institute, Colombo.

Rath, N. and Mitra, A. (1989) Economics of irrigation in water-scarce regions: A study of Maharashtra. Artha Vijñana 31.

Ray, I. and Williams, J. (2002) Locational asymmetry and the potential for cooperation on a canal. Journal of Development Economics 67, 129-155.

Repetto, R. (1986) Skimming the Water: Rent-Seeking and the Performance of Public Irrigation Systems. Research Report No. 4. World Resources Institute, Washington, DC.

Rosegrant, M.W. and Binswanger, H.P. (1994) Markets in tradable water rights; potential for efficiency gains in developing country water resource allocation. World Development 22, 1613-1625.

Saleth, R.M. (1997) India, Chapter 8. In: Dinar, A. and Subramanian, A. (eds) Water Pricing Experience: An International Perspective. Technical Paper No. 386. World Bank, Washington, DC.

Sampath, R.K. (1992) Issues in irrigation pricing in developing countries. World Development 20, 967-977.

Seckler, D. (1996) The New Era of Water Resource Management: From 'Dry' to 'Wet' Water Savings. Research Report No. 1. International Irrigation Management Institute, Colombo.

Shah, T. (1993) Groundwater Market and Irrigation Development: Political Economy and Practical Policy. Oxford University Press, Bombay, India. 
Solanes, M. and Gonzalez-Villarreal, F. (1999) The Dublin Principles for Water as Reflected in a Comparative Assessment of Institutional and Legal Arrangements for Integrated Water Resources Management. TAC Background Paper No. 3. Global Water Partnership, Stockholm, Sweden.

The Economist (1997) Power struggle. 1 November, p. 44.

Tsur, Y. and Dinar, A. (1997) The relative efficiency and implementation costs of alternative methods for pricing irrigation water. The World Bank Economic Review 11, 243-262.

Vermillion, D.L. (1997) Impacts of Irrigation Management Transfer: A Review of the Evidence. Research Report No.11. International Irrigation Management Institute, Colombo.

Wade, R. (1982) The system of administrative and political corruption: Canal irrigation in South India. Journal of Development Studies 18, 287-327.

Wade, R. (1988) Village Republics. Cambridge University Press, New York.

Weinberg, M., Kling, C.L. and Wilen, J.E. (1993) Water markets and water quality. American Journal of Agricultural Economics 75, 278-291. 